\title{
Transição, Consolidação Democrática e Revolução Capitalista*
}

\section{Luiz Carlos Bresser-Pereira}

Professor emérito da Fundação Getulio Vargas, São Paulo, SP. Brasil (e-mail: lcbresser@uol.com.br)

\begin{abstract}
A democracia e regimes democráticos consolidados são um fenômeno do século XX, um século liberal, em que os direitos civis eram assegurados, mas os direitos políticos expressos no sufrágio universal estavam ainda ausentes. Hoje, a democracia é a forma de governo predominante, está consolidada nos países desenvolvidos, e tende a se consolidar nos países de renda média. A democracia tornou-se um valor político tão forte que ninguém a questiona. Cidadãos, acadêmicos e políticos estão sempre criticando seus governos e instituições e têm diferentes ideias normativas sobre a democracia e sobre como aperfeiçoá-la; mas há um consenso tão amplo sobre as virtudes da democracia e os males dos regimes autoritários, e a democracia tem sido a forma de governo estabelecida e preferida há tanto tempo, que ela é geralmente vista como consolidada. Esse consenso, no entanto, é tão recente quanto a própria democracia moderna. Países avançados tornaram-se verdadeiras democracias somente no século $X X$, quando os pobres e as mulheres finalmente conquistaram o direito de votar e de serem eleitos. Por que a democracia se tornou a forma de governo predominante tão tardiamente na história? Por que, desde os gregos, os fi-
\end{abstract}

\footnotetext{
* O autor agradece a Adam Przeworski, Bruce Ackerman, Dietrich Rueschemeyer, Cícero Araújo, Fernando Abrucio, Kurt von Mettenheim, Maria Rita Loureiro, Marcus Mello, Robert Goodin, Simon Schwartzman e dois pareceristas não identificados de DADOS, por seus comentários.
}

DADOS - Revista de Ciências Sociais, Rio de Janeiro, vol. 54, n² 2, 2011, pp. 223 a 258. 
lósofos preferiram alguma forma de monarquia ou de aristocracia à democracia? Reconheço que não há respostas simples para essas questões. Mesmo assim, apresentarei algumas respostas compatíveis com as observações históricas e com as exaustivas pesquisas empíricas realizadas por outros cientistas políticos sobre o assunto. Vivemos em sociedades capitalistas, nas quais, no curto prazo, uma classe dirigente ameaçada pode escolher um regime autoritário; mas, em uma economia de mercado, na medida em que os capitalistas não precisem controlar o governo para sobreviver, eles se tornarão, de início, menos resistentes e, finalmente, favoráveis às demandas da população por democracia.

Neste trabalho, meu argumento é o de que foi a remoção histórica de dois vetos que a classe capitalista impunha à democracia que explicam as transições e, principalmente, as consolidações democráticas. Primeiro, argumento que, depois da revolução capitalista, a nova classe dirigente abandonou o veto que as antigas oligarquias militares e religiosas faziam à democracia porque a apropriação do excedente econômico deixara de depender do controle do Estado, e passava a ser o resultado da realização de lucros do mercado. Em segundo lugar, mostro que, durante todo o século XIX, o medo da expropriação, pelos pobres, que atormentava a burguesia foi gradualmente desaparecendo, e esta acabou aceitando o sufrágio universal. Depois que essas duas condições históricas foram satisfeitas, as preferências se modificaram: a democracia, que era uma demanda dos pobres ou dos trabalhadores, passou a ser racional para a burguesia e para a emergente classe profissional. Em outras palavras, a ascensão do capitalismo e do sistema liberal abriu caminho para que a democracia se tornasse, no século XX, o equivalente do "bom Estado": a forma de governo mais compatível com a estabilidade política e com a conquista dos outros objetivos políticos das sociedades modernas. Os caminhos ou mecanismos que levaram à democracia variaram historicamente de país para país, mas as duas condições necessárias para as democracias consolidadas foram, em primeiro lugar, a revolução capitalista, que deslocou do Estado para o mercado o cenário da apropriação do excedente e, em segundo lugar, a gradual percepção, pela burguesia, de que o sufrágio universal não a levaria a ser expropriada pela classe trabalhadora.

O método que uso aqui é histórico-estruturalista, em vez da abordagem personalista que enfatiza pessoas e lideranças, ou, então, o método que supõe a escolha racional. Nos termos da tradição da sociologia 
política e da política comparativa, estou interessado em generalizar a partir da experiência empírica ou histórica. Para explicar um fenômeno político novo - no caso, a democracia moderna - utilizo o "método do fato histórico novo", no qual o pesquisador deve procurar novos eventos que tenham alterado a realidade social em estudo. O pressuposto é o de que só se pode explicar a transição e a consolidação democráticas com fatos históricos novos. Somente a posteriori, depois de encontrar esses fatos históricos novos que alteraram o objeto em estudo, é que posso buscar as motivações racionais que estão por trás deles, pois as novas condições podem ter tornado racional um comportamento político anteriormente não-racional. A consolidação da democracia exige a combinação da busca de fatos históricos novos com o exame $a$ posteriori dos mecanismos sociais racionais subjacentes ${ }^{1}$.

\section{A VISÃO DOS FILÓSOFOS}

No mundo antigo, a visão normativa sobre o bom regime político era clara: ele deveria ser monárquico ou aristocrático, não democrático. $\mathrm{O}$ máximo que se podia aceitar era o "regime misto" de Aristóteles, no qual alguns aspectos da democracia se combinavam com o regime autoritário. Como o principal objetivo político dos filósofos era a ordem social ou a segurança, eles eram ou francamente autoritários, como Platão, ou moderados, como Aristóteles e Políbio, que estavam preocupados em equilibrar os ricos e os pobres em nome da estabilidade e da justiça. A democracia, por si só, era perigosa, sujeita a facções, instabilidade e corrupção. Atualmente, a antiga democracia grega não pode ser considerada como uma verdadeira democracia, tendo em vista a exclusão das mulheres e dos estrangeiros e a existência de escravos. Mas foi um desenvolvimento político extraordinário - assim como a civilização grega como um todo foi um fenômeno histórico excepcional. Na república romana algumas das características da democracia grega estavam presentes, mas de modo limitado. Somente muitos séculos depois, com as grandes revoluções na França e nos Estados Unidos, inspiradas, como mostrou Pocock (1975), na democracia grega e, especialmente, no republicanismo romano, é que a democracia voltou, mais uma vez, às mentes das pessoas como uma possibilidade. Mas essas seriam, antes, revoluções liberais do que democráticas: elas dão prioridade à proteção dos direitos civis e ao estado de direito sobre a afirmação dos direitos políticos, particularmente o sufrágio universal². Após a democracia grega e a república romana, que ofereceram oportunidades para o pensamento político criativo, a ideia do bom regime político 
reapareceu entre os séculos XIII e XV, no Norte da Itália, sob a forma das cidades-Estado republicanas. A política - a arte de governar por meio da discussão e do compromisso, e não simplesmente pelo uso da força - começou, gradualmente, a reaparecer. A política reapareceu nas cidades-Estado mercantis italianas com os humanistas republicanos e, particularmente, com seu principal representante, Maquiavel. Após muitos séculos, em uma determinada região do mundo, os tempos eram adequados para fazer e pensar a política. Mas, com o surgimento dos modernos Estados nacionais sob a forma de monarquias absolutas, essas oportunidades para a política e para o pensamento político pareceram se enfraquecer. Não exatamente. A Reforma mudou a Europa, em termos políticos e culturais. Por outro lado, considerando que os Estados-nação que estavam surgindo eram o resultado de uma aliança política do monarca com a burguesia emergente, os membros desta classe social começaram a participar da criação de novas instituições. Finalmente, com as revoluções norte-americana e francesa, não apenas a fortuna dos mercados, mas também a época da política e do pensamento político ganharam um novo impulso.

Com a industrialização, a revolução capitalista se completou na Inglaterra, e, logo depois, na França e nos Estados Unidos. A nova economia de mercado exigia um regime político não arbitrário: um Estado liberal, que respeitasse os direitos de propriedade e os contratos e no qual prevalecesse o estado de direito, mas não necessariamente um Estado democrático. Os filósofos políticos estavam ainda longe da democracia; eles viviam em monarquias absolutas e, realisticamente, viam o Estado liberal ou constitucional como uma alternativa. Surgiu uma nova geração de filósofos políticos esclarecidos ou liberais. O liberalismo é originalmente a ideologia da burguesia, mas envolvia um leque de interesses mais amplo. É bem conhecida a esclarecedora teoria de Barrington Moore (1966) que relacionou o liberalismo e a democracia ao a parecimento da "gentry" (pequena nobreza) - um numeroso estrato de proprietários situado abaixo da aristocracia e acima dos ricos camponeses e da nova burguesia. Depois do primeiro grande liberal, Locke, os pensadores liberais foram monarquistas constitucionais. $\mathrm{O}$ liberalismo não era uma alternativa à monarquia, mas uma forma de limitar constitucionalmente os poderes do monarca. Com as revoluções norte-americana e francesa, a ideologia liberal tornou-se dominante, e a palavra "democracia", há muito esquecida, voltou ao debate público. Na Revolução Francesa em particular, houve um projeto democrático radical que se mostrou contraproducente nas mãos dos Jacobinos. Ha- 
bermas (1988:465), escrevendo sobre a Revolução Francesa e sobre a dialética entre liberalismo e democracia, ressalta que "democracia e direitos humanos formam o núcleo universalista do estado constitucional que emergiu das Revoluções norte-americana e francesa em diferentes variantes". No entanto, esse núcleo universalista levaria um século para se tornar realidade. Depois das duas revoluções, os liberais costumavam identificar a democracia com os piores excessos da Revolução Francesa, ou com a ditadura da maioria. À luz de sua experiência histórica, filósofos políticos liberais - como, por exemplo, Benjamin Constant - continuaram hostis à democracia, que acarretaria instabilidade e desordem, demonstrando, assim, a inerente incapacidade do povo de governar. Mesmo Rousseau, que é geralmente associado à democracia, não era realmente a favor da democracia moderna, isto é, representativa. Sendo um cidadão da cidade-Estado republicana de Genebra, ele acreditava apenas na democracia direta. No caso de grandes impérios, ou mesmo Estados-nação, ele tinha a mesma visão de Montesquieu: o governo era muito mais complexo e difícil, e não havia alternativa a algum tipo de despotismo. O critério básico que distingue os regimes liberais dos regimes liberal-democráticos - a inclusão das mulheres e dos pobres como cidadãos - não seria aceito por Rousseau. Como observa Dahl (1989:123):

Ali [no Contrato Social] Rousseau ocasionalmente parece estar afirmando um direito irrestrito a ser membro do demos. Rousseau deixa claro que não é isso que ele pretende. No entanto, elogia Genebra, mesmo se seu demos fosse composto de apenas uma pequena minoria da população. As crianças estavam, evidentemente, excluídas. Mas as mulheres também. E o pior: a maioria dos homens adultos também estava excluída do demos de Genebra.

Os liberais, que haviam sido os filósofos políticos predominantes desde o século XVIII, apoiaram a democracia somente no século XX. Antes, eles a temiam: temiam que os pobres expropriassem os ricos e causassem desordem. Só gradual e lentamente eles foram aceitando a política dos políticos democráticos de dar ao povo direito de voto. Uma razão para isso, de acordo com Bobbio (1991:26), foi o clássico conflito entre razão e democracia.

Na grande tradição do pensamento político ocidental que começou na Grécia, a avaliação da democracia, considerada como uma das três formas ideais de governo, era predominantemente negativa: uma avaliação que se baseia no pressuposto de que o governo democrático, mais 
do que os outros, é dominado por paixões. Como se pode ver, exatamente o oposto da razão.

Na segunda parte do século XIX, porém, as coisas começaram a mudar. Para a economia de mercado, um regime político liberal não era suficiente para proteger os direitos de propriedade e os contratos. A democracia, que costumava ser uma palavra pejorativa, passou gradualmente por uma transformação. Em meados do século XIX, John Stuart Mill, seguindo indicações já existentes nos trabalhos de Jeremy Bentham e de seu próprio pai, James Mill, foi um dos primeiros grandes filósofos a endossar a democracia ${ }^{3}$. De acordo com Macpherson (1966:1-2,9), a pressão daqueles que não tinham voto, mas eram parte do processo de mercado, tornou-se irresistível; por outro lado, escrevendo em meados dos anos 1960, ele observou que "democracia costumava ser um palavrão [...]. Depois, em cinquenta anos, a democracia passou a ser uma coisa boa. Sua plena aceitação nas fileiras da respeitabilidade ficou evidente na época da Primeira Guerra Mundial."

\section{BREVE LEVANTAMENTO DA LITERATURA}

A teoria que esboço neste trabalho vincula a democracia ao desenvolvimento capitalista e, mais especificamente, à revolução capitalista. Uma longa tradição de pesquisa e pensamento sobre as transições democráticas que começa com Lipset (1959) e Cutright (1963) usa uma abordagem histórica e estrutural associada à teoria da modernização e à política comparativa. O clássico trabalho de Lipset sobre desenvolvimento e democracia mostra que quanto mais avançada for uma economia, mais democrática ela tenderá a ser. Lipset usa a teoria da modernização e ressalta a importância da educação - que é, sem dúvida, importante, mas não o bastante para explicar por que a democracia se tornou a forma preferida de governo somente no século XX. Na verdade, seu trabalho seminal estabelece uma correlação, não uma conexão causal. Uma série de outros estudos confirmou a descoberta original de Lipset, mas permaneceu inconclusiva em relação à causa subjacente. O estudo posterior de O'Donnell, Schmitter e Whitehead (1986) apresentou uma abordagem alternativa, enfatizando as particularidades de cada país, as pessoas ou lideranças políticas e as divisões, dentro das elites autoritárias, entre os softliners (moderados) e os hardliners (linha dura). Assim como este trabalho critica a abordagem da escolha racional, que é hipotético-dedutiva e ignora a história, também critica esta segunda alternativa, que vê a democracia como resultado de mudanças nos pro- 
cessos políticos e nas lideranças politicas. A primeira é geral demais, a segunda carece de generalidade e poder explicativo; e ambas deixam de considerar as causas estruturais e culturais subjacentes às mudanças nas instituições. Ambas as abordagens derivam do trabalho de Dankwart Rustow, de 1970, sobre as transições, que criticou a hipótese correta segundo a qual as causas da democratização são também as causas da consolidação. Rustow criou assim espaço para a escolha ou atuação ("agency"); mas esse tipo de abordagem ou leva a modelos racionais abstratos, como os usados no pensamento econômico neoclássico, no qual a escolha se torna simples maximização, ou termina em estudos caso a caso, e a previsibilidade se anula. Em lugar disso, este estudo oferece novas contribuições para a primeira tradição de pensamento, que também é parte da política comparativa, mas busca determinantes estruturais da ação social e política. É um estudo na linha das abordagens de Lipset (1959), Barrington Moore (1966), Dahl (1971), Huntington (1991), e Rueschemeyer, Stephens e Stephens (1992:8), que buscam as forças estruturais existentes por trás das transições e consolidações democráticas ${ }^{4}$. Os últimos citados enfatizam mais do que eu o papel dos pobres na conquista da democracia (o fato de lutarem por ela não significa que a causem), mas fazem uma análise de classes precisa e esclarecedora:

A classe trabalhadora foi a força mais consistentemente pró-democracia [...]. As classes altas dos proprietários de terra, que dependiam de uma ampla oferta de mão-de-obra barata, foram a força mais consistentemente antidemocrática. Verificamos que a burguesia em geral apoiava a instalação do regime constitucional e representativo, mas se opunha à ampliação da inclusão política para as classes inferiores.

Mas, como Rueschemeyer, Stephens e Stephens observam, “as forças causais que estão por trás do relacionamento entre desenvolvimento e democracia permanecem, na verdade, em uma caixa preta" (ibidem:29). De fato, o desenvolvimento capitalista e a democracia aparecem juntos, mas não há uma clara explicação para isso. Este trabalho oferece uma contribuição para a abertura dessa caixa preta em relação às transições e, principalmente, em relação à consolidação democrática. A transição democrática pode seguir diferentes caminhos, mas que, a partir do momento em que a revolução capitalista ou industrial se complete em um país e a transição democrática ocorra, a probabilidade de que ele recaia no autoritarismo é muito pequena ou nenhuma. Antes da revolução capitalista, os países podem se tornar democráti- 
cos por imitação, ou sob pressão externa, mas isso garantirá uma democracia instável; depois dela, outros países podem continuar autoritários durante algum tempo; mas, a partir do momento em que a economia de um determinado país se torne uma economia coordenada pelo mercado em lugar de ser coordenada pelo Estado, que surja uma ampla classe média e que esse país se torne democrático, sua democracia estará consolidada.

Eu sei que não há uma definição "operacional" da revolução capitalista-que é difícil dizer quando um país já formou seu Estado-nação e realizou sua revolução industrial. Sabemos que quando isto acontece o país passa a contar com uma ampla classe de empresários, de trabalhadores, e de uma nova classe média profissional. Que, então, o excedente econômico deixa de ser apropriado por meio do controle do Estado para sê-lo mediante lucros e, mais tarde, também por intermédio de ordenados elevados. Mas não creio que devamos pedir definições operacionais precisas de papers que consideram la longue durée. Este é um trabalho teórico, não um trabalho empírico, no qual eu apresento um modelo de revolução capitalista para explicar a transição e a consolidação democrática. E, naturalmente, além de considerar a experiência histórica, faço uso de pesquisas sobre o tema realizadas por notáveis cientistas políticos.

\section{DOIS CONCEITOS: DEMOCRACIA E REVOLUÇÃO CAPITALISTA}

É hora de deixar claro o conceito formal de democracia que estou usando neste trabalho. É o regime político constitucional em que todos os cidadãos adultos votam (sufrágio universal), as eleições são livres e regulares e a constituição garante o estado de direito, envolvendo liberdade de associação, de expressão e de informação, e proteção aos direitos das minorias. Em outras palavras, entendo como democrático um regime político que satisfaça minimamente os critérios de Dahl que definem uma poliarquia $(1971 ; 1989: 233)^{5}$. No século XX, a democracia ou poliarquia tornou-se finalmente predominante nos países economicamente mais avançados, depois de eles terem adotado o último e mais controvertido elemento da definição de democracia: o sufrágio universal. O Quadro 1 apresenta os primeiros países a adotarem o sufrágio universal até os anos 1940. O primeiro foi a Nova Zelândia, em 1893. A adoção do direito universal de voto não significava que um país tivesse completado sua transição para a democracia, mas na maioria dos países avançados foi exatamente isto o que ocorreu. Esses países eram 
regimes constitucionais ou de estado de direito há muito tempo. A liberdade de pensamento e de associação, além de eleições regulares, também já existiam há algum tempo. Quando os proletários e as mulheres tiveram finalmente direito a voto, as condições mínimas para a democracia se materializaram. Como Santos (1998) observa, no ano em que o sufrágio universal é adotado o número de eleitores dobra, ou mais do que dobra, na maioria dos países. O fato de a democracia ser um fenômeno do século XX fica bastante claro a partir do Quadro 1. A questão é: por que somente nesse momento a democracia se tornou uma forma viável de governo?

Quadro 1

Primeiros Países a Adotar o Sufrágio Universal (até os anos 1940)

\begin{tabular}{|c|c|}
\hline Ano & País \\
\hline 1893 & Nova Zelândia \\
\hline 1902 & Austrália \\
\hline 1906 & Finlândia \\
\hline 1913 & Noruega \\
\hline 1915 & Dinamarca e Islândia \\
\hline 1918 & Áustria e Luxemburgo \\
\hline 1919 & Alemanha e Países Baixos \\
\hline 1920 & Estados Unidos \\
\hline 1921 & Canadá e Suécia \\
\hline 1923 & Irlanda e Uruguai \\
\hline 1928 & Reino Unido \\
\hline 1929 & Equador \\
\hline 1931 & Sri Lanka \\
\hline 1932 & Brasil \\
\hline 1934 & Cuba \\
\hline 1937 & Filipinas \\
\hline 1942 & República Dominicana \\
\hline 1944 & Jamaica \\
\hline 1945 & Itália, Bulgária e Hungria \\
\hline 1946 & França, Japão, Turquia, Polônia, Albânia, Romênia, Panamá e Malta \\
\hline 1947 & Argentina, Venezuela e Paquistão \\
\hline 1948 & Bélgica, Israel, Coréia do Sul e Suriname \\
\hline 1949 & Chile e Costa Rica \\
\hline
\end{tabular}

Fonte: Santos (1998) e o Laboratório de Estudos Experimentais, baseado em Nohlen (1993), Gorvin (1989), e Lane, McKay e Newton (1997). 
Isso representou um terremoto na história da humanidade. A revolução capitalista é a mudança econômica, social, política e cultural que começa com o surgimento de uma classe burguesa e da revolução comercial, e se completa pela formação de cada Estado-nação moderno e sua respectiva revolução industrial. Envolve, no nível econômico, a transição da apropriação do excedente econômico pelo Estado para o lucro como um modo básico de enriquecimento pessoal em uma economia coordenada pelo mercado. Transforma o lucro na motivação econômica, e a acumulação de capital e o progresso técnico nos meios para atingir esse fim. Em nível institucional, implica a separação entre patrimônio público e patrimônio privado ou, em outras palavras, a transição do Estado absoluto e patrimonial, em que a busca de rendas é parte do jogo, para o Estado liberal, no qual isso não mais ocorre e em que os direitos civis dos indivíduos e suas liberdades estão assegurados. Com a revolução capitalista, os novos Estados-nação foram capazes de desenvolver três instituições básicas: o moderno aparelho do Estado com um serviço público profissional, o sistema constitucional e o mercado interno. Em nível cultural, envolve a transição da tradição e revelação como fontes do conhecimento para a razão e a pesquisa científica. Depois da revolução capitalista, além da classe trabalhadora e da burguesia, uma nova e vasta classe média profissional foi gradualmente emergindo e se tornou um fator central na estabilização política.

No pré-capitalismo, a produção estava organizada em nível familiar e o excedente econômico era apropriado por meio da propriedade de terra e, particularmente, pelo uso do poder político para cobrar impostos das pessoas, para reduzi-las à escravidão ou à servidão. Para ser rica, a pessoa precisava ser politicamente poderosa, ser parte da oligarquia que controlava o Estado. A distribuição de renda era essencialmente uma questão política. Desse modo, o controle do Estado, ou poder político, era crucial. E para obter riqueza e prestígio era necessário, em primeiro lugar, que o indivíduo fosse politicamente poderoso. Os grupos dominantes se apropriavam do excedente econômico por meio da guerra; lutavam pelo butim, escravizavam os derrotados ou impunham pesados tributos sobre as colônias, e se apropriavam da terra. À medida que a sociedade foi mudando de tribal para formas mais complexas, como cidades-Estado e impérios, a cobrança de impostos passou a ser cada vez mais importante. A aristocracia militar, com o apoio de uma burocracia patrimonial e de uma hierarquia religiosa, apropriou-se do excedente econômico dos comerciantes, enquanto os proprietários de terras cobravam aluguéis dos camponeses. Alegitimidade re- 
ligiosa foi sempre uma parte essencial do processo, mas a própria existência de impérios e oligarquias dominantes dependia da capacidade destes de deter poder político e fazer a guerra. Na última forma de organização do Estado pré-capitalista, o Estado patrimonial, a cobrança de impostos era essencial para financiar a aristocracia da corte e a burocracia patrimonial. Não havia separação entre o patrimônio público e o patrimônio privado: ser economicamente rico dependia de ser politicamente dominante. Os pobres, identificados desde Aristóteles como patrocinadores da democracia, costumavam pressionar por liberdade, por algum tipo de democracia, mas o grupo dominante resistia, recorrendo a todas as formas de violência para manter o Estado sob seu controle político. Como os mercados tinham apenas uma existência marginal, não havia outra maneira de distribuir riqueza e renda senão mediante o controle do Estado. Ocasionalmente, o povo, ou os comerciantes, podiam ganhar algum poder e estabelecer alguma forma de república, mas os poderosos interesses envolvidos no poder político logo iriam corromper e eliminar o novo regime. Depois da revolução industrial, essa situação mudou dramaticamente. Agora os sistemas constitucional e de mercado coordenam a sociedade. Agora os lucros e altos salários ganham importância no enriquecimento das pessoas, enquanto os aluguéis e a cobrança de impostos perdem importância. O Estado continua a desempenhar um papel na aquisição e distribuição da renda, mas não é mais uma condição para a existência da elite econômica. Não é fácil determinar se um país passou por uma revolução capitalista, mas, além da riqueza, uma boa medida é saber se a busca de rendas, a captura patrimonial do Estado, ainda desempenha um papel importante no enriquecimento das pessoas.

A revolução capitalista não criou a democracia, mas tornou-a possível. A nova classe capitalista podia fazer agora o que as classes dominantes anteriores não podiam: tinha a opção de não vetar a democracia, uma vez que o controle absoluto do Estado não era mais uma condição necessária de sua riqueza. A partir desse momento, a rejeição aos regimes autoritários ganhou impulso, e o consenso contra a democracia desapareceu. Como observa Dunn (1979:8), a "rejeição da viabilidade da democracia era uma boa síntese de um consenso intelectual europeu que datava pelo menos do Principado de Augusto, um consenso que desapareceu com surpreendente rapidez entre 1776 e 1850 na própria Europa". Assim, tudo mudou com o longo processo histórico que foi a revolução capitalista. À medida que a economia de mercado prevalecia, o novo grupo dominante não precisava mais recorrer à violência 
ou ao controle do Estado para se apropriar do excedente econômico. De acordo com Celso Furtado (1976:33):

Duas formas de apropriação do excedente parecem ter existido desde o início dos tempos históricos. De um lado está o que chamamos de forma autoritária, que consiste em extrair o excedente por meio de coerção. De outro lado temos a forma mercantil, ou seja, a apropriação do excedente por meio da troca [...]. O excedente utilizado para se apropriar de outro excedente é o capital, o que nos permite dizer que todas as formações socioeconômicas nas quais o excedente é predominantemente capturado por meio da troca pertencem ao gênero capitalismo.

Furtado não estava discutindo o aparecimento da democracia, mas este contraste entre a forma autoritária e a forma mercantil de apropriação do excedente foi a semente da teoria que estou apresentando aqui. No momento histórico em que cada sociedade nacional passou da apropriação autoritária para a apropriação mercantil ou capitalista do excedente, o poder do Estado deixou de ser uma condição necessária para adquirir riqueza. Os Estados continuaram a desempenhar um papel importante que, no entanto, não era mais o de sustentar a apropriação oligárquica, mas o de criar as condições institucionais para o investimento e a realização de lucros no mercado. O controle do Estado continuou a ser crucial para a nova classe dirigente, mas os homens de negócio podiam deixar a responsabilidade de governar e de proteger militarmente os novos Estados-nação de agressões externas aos membros da antiga aristocracia ou a uma nova classe de políticos profissionais que então surgiu. A condição, mais do que apenas proteger direitos de propriedade e contratos, era de que eles criassem instituições que estimulassem a atividade econômica.

Nesse momento, quando o argumento e a persuasão prevaleceram sobre a força, começou a era da política. As pessoas tinham então a possibilidade de discutir e criar instituições liberais e democráticas. O século XVIII já havia experimentado uma indicação disso quando alguns pensadores contrastaram a dureza da aristocracia com a suavidade do capitalismo. Montesquieu, principalmente, ressaltou a "douceur" do comércio ${ }^{6}$. Albert Hirschman (1977), comentando essa visão, observa que, enquanto os aristocratas guerreiros estavam sujeitos a grandes e, às vezes, heroicas paixões, a burguesia limitava-se a características mais modestas e moderadas. Analisando Shaftsbury, Hutcheson e Hume, ele mostra como esses filósofos encaravam a atividade econômica como uma "calma paixão". A Inglaterra foi o primeiro país a com- 
pletar sua revolução industrial; não por acidente, foi também o primeiro Estado-nação e o primeiro regime político liberal no mundo. No início do século XIX, a Inglaterra estava pronta para o liberalismo, não para a democracia. O primeiro veto à democracia, que refletia a necessidade de apropriação autoritária do excedente, havia sido mais ou menos eliminado, mas o medo da expropriação pelos pobres continuava forte. Os direitos civis poderiam ser assegurados, não os direitos políticos. Na verdade, já havia sido estabelecido um regime constitucional um século antes, na Revolução Gloriosa, mas o século XIX seria a época em que o liberalismo clássico floresceria e se tornaria predominante.

\section{O ARGUMENTO BÁSICO}

Nos primeiros países que se tornaram democráticos, a transição para a democracia foi produto de quatro fatos históricos, dos quais a revolução capitalista é o primeiro e mais abrangente; os outros três são o aumento da capacidade de organização dos trabalhadores, a perda gradual do medo dos capitalistas de serem expropriados por um governo socialista, e o surgimento de amplas classes médias entre os trabalhadores e os ricos. Antes da revolução capitalista a aristocracia impunha um veto absoluto à democracia. Barrington Moore já havia notado esse fato. Em sua discussão da coalisão política que reuniu a burguesia inglesa com a aristocracia proprietária de terras, Moore é claro:

Uma classe forte e independente de habitantes da cidade tornou-se um fator indispensável ao crescimento de uma democracia parlamentar; sem burguesia não há democracia [...] a burguesia inglesa do século XVII, até grande parte do século XIX tinha o maior interesse material na liberdade dos cidadãos. (Moore, 1966:418, 424, tradução nossa)

A conclusão da revolução capitalista em cada país foi o fato histórico novo mais geral que tornou a democracia viável e, por fim, desejável; foi a causa direta da remoção do primeiro veto. Durante todo o século XIX a democracia gradualmente se tornou o equivalente do bom Estado, na medida em que demonstrou ser a mais estável forma de governo e, mais amplamente, a forma de governo que, apesar dos conflitos de classe, melhor promovia os interesses de todas as classes sociais. Depois da revolução liberal, os capitalistas haviam temido que a democracia permitisse aos trabalhadores optarem pelo socialismo. Esse medo diminuiu gradualmente, na medida em que os trabalhadores 
não demonstraram ter esse objetivo. Assim, no início do século $X X$, acabamos tendo as primeiras verdadeiras democracias. Como afirma Dahl (1989:234), "embora algumas das instituições da poliarquia tenham surgido em uma série de países europeus e de língua inglesa no século XIX, em nenhum país os demos se tornaram inclusivos até o século $X X^{\prime \prime}$.

A revolução industrial abriu caminho para o Estado liberal, mas não para o Estado democrático. O controle do Estado continuava sendo naturalmente um objetivo político central para os grupos dominantes, por duas razões: o Estado continuava a desempenhar um importante papel na distribuição da renda e um papel central na garantia da ordem pública. Durante, e imediatamente após a transição para a economia de mercado, um dos papéis do Estado, além de garantir os direitos de propriedade e os contratos, foi o de criar condições para aumentar a acumulação de renda para financiar o crescimento econômico. A nova classe capitalista, formada por uma ampla classe média e uma pequena classe alta, seria uma classe liberal. Seus membros lutavam não apenas por lucros, mas também pela garantia de seus direitos civis duramente conquistados. A memória da dominação arbitrária que havia caracterizado o absolutismo estava viva e presente. Com a ordem liberal, eles haviam deixado de ser súditos para se tornarem cidadãos dotados de direitos.

\section{TRÊS NOVOS FATOS HISTÓRICOS ADICIONAIS}

Mas foram necessários três novos fatos históricos adicionais para que a democracia fosse, afinal, vitoriosa. O primeiro deles foi a perda do medo da expropriação. Havia um segundo veto - este da burguesia, e não da aristocracia - à democracia. Da mesma forma que levou tempo para a aristocracia conceder total cidadania à burguesia, também levaria tempo para a nova classe empresarial aceitar que os trabalhadores tivessem pleno direito a voto. A nova classe capitalista era liberal, mas não democrática. Embora as sementes da democracia estivessem no Estado liberal, os liberais clássicos combateram a democracia principalmente durante a primeira metade do século XIX. Faziam isso em nome da liberdade; o argumento era de que a liberdade e a igualdade conflitavam entre si, que a igualdade de direitos - que é uma condição da democracia - seria intrinsecamente incompatível com as liberdades cívicas. Da igualdade de direitos, a democracia iria diretamente para a tirania da maioria e a negação da liberdade. Como ressalta Lindblom 
(1977:163), os primeiros filósofos políticos modernos "são todos, em primeiro lugar, liberais e, em segundo lugar, democratas, se é que realmente o são [...]. Os Criadores da Constituição [norte-americana] eram liberais fervorosos, mas não mais do que democratas de ocasião, e alguns não eram democratas de modo algum". Lindblom também vê uma estreita relação entre poliarquia e capitalismo, que ele chama de "o sistema de mercado da iniciativa privada". Ambos seriam "métodos para o controle popular sobre as decisões 'públicas'", o primeiro por meio do voto, o segundo por meio das preferências individuais dos consumidores.

A democracia só se materializou realmente no início do século XX porque foi nessa época que o segundo veto - o medo da expropriação dos ricos pelos pobres - foi abrandado. Depois da conclusão da revolução capitalista, a democracia passou a ser uma possibilidade real, mas a nova classe dirigente capitalista percebeu que seu advento poderia envolver a vitória dos trabalhadores nas eleições e o estabelecimento de um regime socialista. Era o argumento liberal da ditadura da maioria que surgia. Esse medo desapareceu gradualmente, levou um século para que desaparecesse. Aos poucos foi ficando claro que na coalizão burguesa-aristocrática do século XIX, trabalhadores não votavam necessariamente em partidos socialistas, nem apoiariam uma revolução socialista.

Um segundo fato histórico adicional à revolução capitalista foi o aumento do poder que a classe trabalhadora, reunida em grandes fábricas, conquistou à medida que se tornou mais bem organizada e mais exigente. Os trabalhadores não eram socialistas, mas percebiam que a democracia lhes era favorável. É preciso, porém, observar que a classe trabalhadora não teve força para mudar o regime político enquanto as elites mantinham seus vetos. No momento em que esses vetos foram sendo abrandados, porém, o papel dos pobres na conquista da democracia não pode ser ignorado. Eles não eram revolucionários: exigiam democracia, mais do que socialismo. Pouco a pouco, os capitalistas perceberam que os trabalhadores não votavam em bloco, e que a maioria destes não votaria a favor da expropriação dos ricos. Eles observaram que a política democrática tendia a dividir ideologicamente os partidos políticos, mas as diferenças entre eles tenderiam a ser cada vez menores, na medida em que todos tinham de convergir para um centro ideológico. Em outras palavras, os capitalistas perceberam que uma tendência nítida para eleições democráticas envolvia uma mu- 
dança de políticas, mas não de regime econômico. No final do século XIX, os argumentos contra o sufrágio universal tinham perdido força, já que a burguesia havia percebido que seu temor de expropriação pelos trabalhadores não tinha fundamento ${ }^{7}$.

O surgimento de duas grandes classes médias - uma burguesia e uma classe média profissional (esta última dividida em funcionários públicos e administradores privados, pessoal técnico e administrativo) - reforçou essa percepção, e é o terceiro fato histórico adicional que criou as condições para a transição e, como veremos, para a consolidação da democracia. Como Rueschemeyer, Stephens e Stephens (1992:14) enfatizam, "a classe média surge como a principal força pró-democracia na análise de Lipset". À medida que a industrialização avançava, uma nova classe média profissional, que já existia no aparelho do Estado, surgia dentro das novas grandes empresas comerciais. As duas classes médias começaram a representar uma parcela cada vez maior da população total. Situadas entre os ricos e os pobres, elas eram também uma razão para que os ricos temessem menos os pobres e fossem convencidos a aceitar o sufrágio universal. A remoção do segundo veto à democracia - o fim do medo da expropriação - estava se materializando.

Assim, nos primeiros países democráticos, quatro fatos históricos - a revolução capitalista alterando a forma de apropriação do excedente; $o$ gradual desaparecimento do medo da expropriação; o aumento da capacidade organizacional dos trabalhadores; e o surgimento de grandes classes médias - contribuíram para o aparecimento e a consolidação da democracia. Um fato fundamental - a revolução capitalista abrange os demais - e três fatos históricos adicionais que contribuíram para a remoção dos vetos à democracia. Se a democracia foi conquistada, foi uma vitória dos pobres $^{8}$, mas sua luta não foi revolucionária, porque ela mudou não o regime econômico, mas somente o regime político, e a mudança que ocorreu na classe trabalhadora foi menos estratégica para a transição do que a mudança que ocorreu na elite.

Esse importante processo histórico envolveu conflitos e compromissos. Assim como a primeira transição - do Estado absoluto para o Estado liberal - exigiu que a aristocracia dividisse o poder com a burguesia, a segunda, do Estado liberal para o Estado liberal-democrático, trouxe necessariamente os trabalhadores para dentro do processo político. Para ambas as transições, a revolução capitalista e os três outros fatos históricos novos acima mencionados foram necessários; eles ex- 
plicam a transição e a consolidação em geral. No entanto, eles não foram suficientes para a transição para a democracia; foram, apenas, a condição para a consolidação democrática, uma vez ocorrida a transição.

\section{MOTIVOS RACIONAIS A POSTERIORI}

O complexo processo político derivado das revoluções capitalista e industrial levou o mundo a uma ampla transição democrática, e os países ricos e de renda média que completaram essa revolução, a constituírem democracias consolidadas. Nestes últimos, a democracia, que era originalmente uma demanda dos pobres ou da classe trabalhadora, tornou-se gradualmente uma opção racional para as classes médias e para a rica classe capitalista. Ao contrário da antiga aristocracia de proprietários de terras, a nova burguesia dependia menos do Estado e valorizava mais as liberdades asseguradas pela democracia liberal. Assim, eles gradualmente mudaram suas concepções sobre a democracia, seja porque se sentissem pressionados, seja porque tivessem interesse em fazer isso. Em primeiro lugar, a classe capitalista percebeu que os pobres não representavam realmente uma ameaça, porque não tinham uma alternativa real ao sistema capitalista. Em segundo lugar, ela se conscientizou de que o regime democrático poderia ser mais estável, mais eficaz na garantia da ordem social, do que simplesmente um Estado liberal em que o poder supremo estava nas mãos de um soberano ou de um governante. E, em terceiro lugar, ela percebeu que a propriedade e os lucros não estavam realmente ameaçados pela democracia. Em outras palavras, ao contrário da antiga aristocracia, os novos ricos não eram intrinsecamente opostos à democracia; eles eram intrinsecamente liberais, mas, como o capitalismo não era um jogo de soma zero, perceberam que o liberalismo combinado com a democracia poderia proteger adequadamente seus interesses, independentemente do fato de também proteger os pobres e as classes médias.

De acordo com o modelo de revolução capitalista para explicar a transição e a consolidação democrática que estou apresentando aqui, quando a rica classe empresarial percebeu que poderia continuar realizando lucros sem ter o controle direto do Estado, ela escolheu a democracia não tanto porque a pressão das classes inferiores havia crescido, mas principalmente porque percebeu que essa era uma maneira mais eficaz e estável de garantir a ordem pública, os direitos de propriedade e os contratos, do que a alternativa autoritária. Ao endossar a democra- 
cia, os ricos perdiam poder político, mas não muito. Eles sabiam que poderiam contar com os partidos políticos conservadores e mesmo com os social-democráticos para protegê-los, já que controlavam os investimentos e o crescimento econômico, ou exerciam poder de veto sobre eles. Os ricos mantinham o controle da forma de financiamento das campanhas eleitorais, e também da mídia. Faziam concessões quanto ao poder político, mas não quanto aos valores e princípios políticos liberais: eles se asseguraram de que a proteção das minorias e dos direitos civis continuasse como elemento central de cada constituição nacional.

Esse modelo histórico da transição global para a democracia que ocorreu no século XX só tem sentido a posteriori, historicamente, sob duas condições: primeiro, de que, do ponto de vista dos trabalhadores, uma revolução socialista não fosse racional; segundo, de que uma taxa de lucro satisfatória de longo prazo estivesse assegurada para os capitalistas. A primeira condição foi esclarecida por Przeworski (1985:139, $177,180)$ que analisou de modo convincente a racionalidade dos trabalhadores em se recusarem a apoiar uma revolução socialista. De acordo com ele, os trabalhadores, nas democracias avançadas, tinham fortes motivos para não sentirem nenhuma atração por uma revolução que expropriasse os ricos. Se os trabalhadores tivessem o direito de votar, eles racionalmente votariam nos partidos políticos socialistas comprometidos com a revolução socialista. Mas não o fazem porque, de um lado, na medida em que os capitalistas controlam os investimentos, eles "estão em uma posição única no sistema capitalista: eles representam os futuros interesses universais, enquanto os interesses de todos os outros grupos aparecem como particularistas e, portanto, como inimigos de desenvolvimentos futuros". Por outro lado, de acordo com Przeworski, os trabalhadores não tinham garantia de que a mudança para o socialismo iria imediatamente melhorar suas condições materiais. Ao contrário, eles não têm certeza de que o socialismo seja mais eficiente do que o capitalismo e, mesmo se o for, a transição para o socialismo poderá envolver uma deterioração do bem-estar dos trabalhadores. Portanto, conclui ele, uma vez que "os trabalhadores têm a opção de melhorar sua condição material cooperando com os capitalistas, a orientação socialista não pode ser deduzida dos interesses materiais dos trabalhadores".

A segunda condição - de que o desenvolvimento capitalista mantém a taxa de lucro em um nível satisfatório ou, nas palavras de Herbert Si- 
mon (1957), em um nível gratificante a longo prazo- é um fato empírico. Após a revolução industrial, a taxa de lucro não caiu conforme previsto pelos economistas clássicos, mas manteve-se razoavelmente constante em nível satisfatório, do ponto de vista dos empresários investidores. No nível teórico, Bresser-Pereira (1986; 2004), em seu modelo clássico revisado de crescimento e distribuição, argumentou que a taxa de lucro, não a taxa de salários, deveria ser considerada como dada ou constante no processo de crescimento de longo prazo, enquanto os salários deveriam ser vistos como o resíduo. Partindo da inversão do modelo clássico de distribuição, ele mostrou que os salários aumentam a uma velocidade inferior, igual ou superior à produtividade, dependendo do tipo de progresso técnico: consumidor de capital, neutro ou poupador de capital. Por que a taxa de lucro é constante a longo prazo? Essencialmente porque, de um lado, uma taxa de lucro satisfatória - aquela que mantém os empresários inovando e investindo - é condição para o desenvolvimento capitalista, e porque, de outro lado, dada a capacidade do capitalismo de inovar e aumentar a produtividade, não há nenhuma forma de organização econômica alternativa ao capitalismo9 . Assim, os aumentos salariais dos trabalhadores dependem de uma taxa de lucro satisfatória. Em outras palavras, as "contratendências à queda da taxa de lucro" mencionadas por Marx tinham de prevalecer: as sociedades capitalistas sempre desenvolvem tecnologias, instituições e ideologias que asseguram uma taxa de lucro satisfatória. $\mathrm{Na}$ medida em que salários e ordenados aumentam ao mesmo tempo em que a produtividade cresce, a taxa de lucro é mantida constante a longo prazo - o que significa que o jogo entre os ricos e os pobres não era um jogo de soma zero, mas um jogo em que todos podem ganhar, o que torna a democracia muito menos ameaçadora do que se pensava inicialmente.

Essas duas condições reforçam-se mutuamente. De um lado, os trabalhadores não tinham motivo racional para apostar na revolução socialista; de outro, como os salários aumentavam aproximadamente na mesma velocidade que a produtividade, eles tinham bons motivos para continuar participando do sistema econômico. O fato de que os trabalhadores, no final, não tivessem nenhuma opção melhor foi percebido não apenas por eles, mas também pelos capitalistas. Assim, na medida em que estes últimos compreenderam esse fato, viram cada vez menos razões para temer a democracia. Ao contrário, tornaram-se cada vez mais confiantes nela. O aumento dos benefícios diretos e sociais trazido pela democracia não seria um ônus desde que esses benefí- 
cios não ameaçassem a taxa de lucro de longo prazo. Os aumentos salariais poderiam sustentar a taxa de lucro na medida em que mantivessem a demanda efetiva, como Keynes demonstrou. Assim como acabou sendo racional para os trabalhadores individualmente, não apenas como classe, apoiar o capitalismo e lutar pela democracia e por direitos sociais, assim também acabou sendo racional para os capitalistas apoiar a democracia, embora resistissem às iniciativas de bem-estar social. Os trabalhadores compreenderam cada vez mais os limites de suas demandas salariais, enquanto os capitalistas ficaram cada vez mais convencidos de que a democracia poderia facilitar as demandas dos trabalhadores, mas, em compensação, fornecer um sistema político legítimo mais capaz de garantir a estabilidade política do que o regime autoritário. Além disso, os capitalistas perceberam que a democracia tornava o estado de direito muito mais seguro - e nada é mais importante para a atividade comercial do que um ambiente constitucional e legal estável.

Nesse modelo, o crescimento de uma ampla classe média burguesa e profissional entrou como um fator moderador para reduzir o conflito entre os ricos e os pobres. No entanto, se entendermos que a classe média era parte da classe dirigente ampliada que caracteriza as sociedades modernas, percebemos imediatamente que ela também tinha um grande interesse na democracia. Sendo muito maior do que a antiga aristocracia, a nova classe dirigente formada pelos ricos e pela alta classe média precisava de instituições que permitissem a grupos dentro dela dividirem poder político ou se alternarem no governo de modo ordenado. Nessas circunstâncias, a democracia era a escolha racional óbvia, coletivamente e para cada membro. As instituições democráticas criavam condições para a resolução de seus conflitos internos. Os grupos aristocráticos, embora afligidos por violentas lutas internas, eram sempre pequenos. Eles solucionavam seus conflitos pessoalmente. A nascente classe capitalista, por ser grande, tinha na democracia uma maneira melhor e mais segura de resolver seus conflitos.

Assim, gradualmente, todos os principais atores políticos perceberam que a democracia era a forma de governo mais favorável, tanto para os negócios como para os trabalhadores. Estava terminada a época em que as facções gananciosas e turbulentas mencionadas pelos filósofos gregos atormentavam a democracia. Durante muito tempo, as democracias que seguiram os passos discutidos aqui enfrentariam crises e 
agitações, mas elas representavam um aumento relativo significativo da estabilidade política. Trabalhadores, capitalistas e as classes médias assinaram informalmente um novo contrato social ou político. A luta pela justiça, a condenação da corrupção e dos privilégios, e a possibilidade de construir modelos mais eficientes e mais justos de capitalismo continuam a ser importantes tarefas políticas, mas a democracia se estabeleceu como a forma universalmente preferida de conduzir esses esforços republicanos.

Como comparar este meu argumento com os de Charles Boix (2003), Boix e Stokes (2003) e Acemoglu e Robinson (2006) sobre as transições democráticas? Eles adotam a abordagem da escola da escolha racional e buscam motivos racionais a priori para elas. Eles argumentam que o desenvolvimento econômico causa a democracia porque quando a distribuição da renda é mais igual (como aconteceria no capitalismo) o medo de redistribuição por meio de impostos desaparece. Assumem, portanto, que há uma relação linear entre desenvolvimento e distribuição, o que é muito discutível. Como Edward Muller (1997) mostrou, a relação entre desenvolvimento e desigualdade tem forma de $U$, mas nos últimos 30 anos nem mesmo essa forma está assegurada. Segundo, eu não vejo a transição democrática como uma simples vitória dos trabalhadores. De acordo com Acemoglu e Robinson (2006: XII) “dado que a democracia representa uma mudança de poder em favor dos cidadãos, por que a elite criaria esse conjunto de instituições? Nós argumentamos que isto ocorre porque cidadãos livres podem ameaçar e forçar a elite a fazer concessões". Isto é muito simples e explica pouco. Por que os cidadãos venceram? E até que ponto eles foram cooptados pelos ricos? Por outro lado, por que não considerar os ganhos da classe capitalista e da classe profissional com a democracia - principalmente mais segurança para alcançar lucros satisfatórios e ordenados elevados no quadro da democracia?

\section{CONSOLIDAÇÃO DEMOCRÁTICA}

A explicação apresentada aqui de por que a democracia acabou sendo preferida apenas no século XX é útil para explicar a transição geral para a democracia ocorrida nesse século, mas não explica as transições dos países individualmente. Como argumentado por Collier (1999:20), muitos são os caminhos para a democracia, "na maioria dos casos a política de democratização é uma combinação de processos que vêm de cima e de baixo, envolvendo combinações de interesses de classes, ato- 
res estratégicos e formas, locais ou áreas de atuação". Além disso, influências externas podem levar a transições democráticas que, de outra forma, não ocorreriam (pensemos no Haiti, por exemplo), ou, no lado oposto, dirigentes autoritários bem-sucedidos podem permanecer no governo muito além do que a evolução das variáveis econômicas e sociais nos levaria a prever, como no caso de Cingapura.

O modelo histórico apresentado aqui, no entanto, é eficaz para explicar a consolidação democrática. Podemos encontrar muitas características que são comuns às democracias consolidadas, mas elas não explicam a consolidação democrática - apenas definem uma democracia estável. Por outro lado, quando um país faz sua transição para a democracia depois de ter completado sua revolução capitalista e industrial, podemos prever que ele provavelmente continuará sendo democrático. Somente um país que tenha completado essa revolução terá a estrutura social, a cultura política e as instituições que são exigidas por uma democracia consolidada. Um país pode importar instituições democráticas, mas é impossível importar a estrutura social que torna a democracia racional para as elites econômicas e políticas, ou importar a respectiva cultura democrática necessária a um regime consolidado. Quanto mais totalmente capitalista for um país, mais consolidado tenderá a ser seu regime democrático. Essa afirmação, porém, não significa que a consolidação democrática somente possa ser explicada pela revolução capitalista. Outros fatores, principalmente a desigualdade, também desempenham um papel. Como a conclusão de uma revolução capitalista não é um episódio preciso, mas um processo histórico, dentro desse processo, quanto mais desigual for uma sociedade, provavelmente mais tempo será necessário para que ela chegue à consolidação democrática (Muller, 1997). Embora, como Dahrendorf (2000:311) adequadamente observa, "a democracia dê a impressão de estar sempre em crise", a permanente insatisfação dos cidadãos com suas democracias não representa uma ameaça a elas, mas uma maneira de aperfeiçoá-las. Desde a Segunda Guerra Mundial, as democracias desenvolvidas têm se mantido estáveis, e embora a confiança pública na democracia nem sempre tenha sido satisfatória, não podemos dizer que a democracia corra risco nos países desenvolvidos, ou nos países de renda média que fizeram sua transição para a democracia depois que as condições econômicas e sociais para tanto estiveram presentes.

Linz e Stepan (1996:55) tentaram englobar todas as formas de transição e consolidação com o auxílio de quatro tipos de regime não democráti- 
co cujas características influenciariam decisivamente os caminhos da transição e da consolidação. A partir daí, eles descreveram o típico arcabouço institucional, cultural e econômico existente logo antes da transição em um dos quatro tipos de regime não democrático, a saber, o tipo autoritário: "uma sociedade civil sólida, uma cultura legal que dá suporte ao constitucionalismo e ao estado de direito, uma burocracia estatal em boas condições, que opera dentro de normas profissionais, e uma sociedade econômica razoavelmente bem institucionalizada". De acordo com eles, a Espanha, por exemplo, apresentava essas condições no início dos anos 1970; o Brasil, eu acrescentaria, é outro exemplo disso, dez anos mais tarde. Os dois autores não se referem à revolução capitalista, mas nenhum país que não tenha passado por uma revolução capitalista terá essas características. Por outro lado, um país oriundo de outro dos quatro tipos, como o Haiti e o "sultanismo", poderá passar por uma transição, mas essas condições não existirão e a democracia será eminentemente instável. Na verdade, além da renda per capita, as características que Linz e Stepan listaram são uma boa maneira de avaliar se um país completou sua revolução capitalista.

Nos anos 1970 e 1980, cientistas políticos estiveram envolvidos em grandes estudos sobre as transições para a democracia. Depois de muitos episódios de transição, a preocupação se voltou para a consolidação democrática e a qualidade da democracia. Neste trabalho, não estou discutindo este último assunto, mas o anterior é fundamental para ele. A discussão sobre a qualidade da democracia na América Latina é marcada pelo conceito de O'Donnell $(1991$; 2004) de democracia delegativa e por sua mais recente discussão sobre direitos humanos e democracia. Mas não devemos exigir da democracia mais do que um regime político pode oferecer, nem voltar a cair na velha distinção entre democracia formal e democracia substantiva. Em lugar disso, e de acordo com uma abordagem histórica não limitada à América Latina, Huber, Rueschemeyer e Stephens (1997) veem três formas sucessivas de democracia após a democratização - democracia formal, participativa e social - na medida em que o regime político garanta, além de sufrágio livre e universal, responsabilidade (accountability) e liberdade de expressão, altos níveis de participação e igualdade crescente nos resultados sociais e econômicos. Por seu lado, Bresser-Pereira (2004) sugere que, a pós a transição, a primeira forma de democracia será a aquela de elites ou liberal, seguida pela democracia social ou da opinião pública, que, possivelmente, tenderá à democracia participativa, e, mais adiante ainda, à deliberativa. Apesar de diferenças de terminologia, os 
autores propõem que os países que experimentam desenvolvimento político após uma transição democrática que atenda ao conceito mínimo de democracia movem-se em direção a formas mais exigentes de organização política. Formas novas e mais desenvolvidas de democracia, mais responsáveis, mais representativas, envolvendo mais igualdade substantiva e mais participação política evoluem no decorrer do tempo, juntamente com mais crescimento econômico, melhor institucionalização e mais desenvolvimento de valores democráticos.

Quanto à consolidação democrática, encontramos a mesma linha divisória teórica, entre a abordagem histórica ou socioeconômica, e a abordagem de processos e liderança, que a existente na discussão sobre as transições democráticas ${ }^{10}$. A segunda, em suas manifestações mais radicais, esvazia a consolidação de seu conteúdo histórico real. Diamond (1997:xxxii), por exemplo, rejeita a "explicação estruturalmente determinista" e afirma que "a oportunidade de desenvolvimento e consolidação democráticos não está descartada para nenhum país, por mais pobre que seja". Outros pesquisadores ofereceram algumas contribuições valiosas, mas foram mais bem-sucedidos ao definir uma democracia consolidada do que ao explicar por que ela se torna consolidada. Linz (1990:156) definiu classicamente a consolidação democrática como uma situação "na qual nenhum dos principais atores políticos, partidos ou interesses organizados, forças ou instituições considera que haja uma alternativa ao processo democrático para chegar ao poder, e [...] nenhuma instituição ou grupo político tenha o direito de vetar a ação de tomadores de decisão democraticamente eleitos". O'Donnell (1997:43), rejeitando a separação entre qualidade e formas históricas de democracia, rejeita a visão minimalista de democracia implícita na definição de Linz, e observa: "não vejo muito ganho analítico em associar o termo 'consolidado' a algo que provavelmente, embora não certamente, perdurará". Assim, ele não reconhece que uma democracia de elites - a primeira forma de democracia que geralmente surge da transição e, por essa razão, uma democracia de acordo com seu conceito mínimo - possa ser uma democracia consolidada, mesmo se a experiência histórica o demonstra. Schmitter (1997:247) ressalta que "a presença da sociedade civil contribui (positivamente) para a consolidação da democracia" - o que é verdade, mas não explica quais são as condições históricas que abrem espaço para uma sociedade civil ativa e sólida. Valenzuela (1992:63) observa corretamente que o primeiro passo para elucidar a consolidação democrática é associar a ela uma definição mínima de democracia, mas, posteriormente, ele se limita a estabe- 
lecer como um requisito para uma democracia consolidada uma "complexa institucionalização", que ele contrapõe a uma "perversa institucionalização". De acordo com ele, "uma democracia consolidada seria aquela que não tem elementos perversos minando suas características básicas", mas ele imediatamente reconhece que "a lista de tais perversidades não pode ser ampliada infinitamente". Nessa mesma linha de pensamento, Carey (1997:68) tenta mostrar "por que a análise institucional é de particular importância para a consolidação das democracias". De fato, as democracias consolidadas geralmente têm instituições democráticas fortes, assim como uma cultura razoavelmente democrática, mas essas afirmações apenas definem ou caracterizam a consolidação, sem explicá-la.

Seguindo uma abordagem diferente, Huber, Rueschemeyer e Stephens (1997) argumentam que "após um súbito aumento de mobilização durante a transição, o equilíbrio dos poderes se voltou contra as classes subordinadas" - e esse fato se tornou um obstáculo à consolidação democrática. Com relação à transição democrática brasileira, Weffort (1984) argumentou que ela se tornou conservadora na medida em que o processo acabou ficando sob o controle da classe empresarial industrial. Isso realmente ocorreu, mas foi provavelmente uma das razões pelas quais a democracia brasileira é uma democracia consolidada. Mainwaring (2000), buscando as causas do aumento da sobrevivência das democracias na América Latina, encontra três fatores de explicação: “a primeira explicação se desenvolve em torno das transformações estruturais desencadeadas pela modernização [...] em segundo lugar, da esquerda para a direita do espectro, as atitudes políticas se alteraram [...]. Finalmente, o a poio internacional à democracia, especialmente dos Estados Unidos, aumentou [...]." Em outras palavras, dado que "modernização" é um outro nome para revolução capitalista, e "atitudes políticas" um substituto para a cultura política, Mainwaring está adotando uma abordagem histórica condizente com a visão apresentada aqui.

Na crescente literatura sobre transição democrática, a contribuição de Alexander (2002:57) é particularmente relevante. Apesar de adotar uma abordagem da escolha racional, ele consegue apresentar um quadro amplo do processo de consolidação. Mas não oferece uma solução para o próprio problema que ele define como central: "o que leva a direita a esperar que seu bem-estar e segurança estarão previsivelmente mais bem garantidos na democracia do que no regime autoritário?" A 
questão está de acordo com o modelo apresentado neste trabalho, porque situa os problemas nas preferências dos ricos ou da classe capitalista em relação à democracia e porque Alexander mostra que essa classe pode racionalmente mudar suas preferências à medida que surgirem novos fatores. Como aconteceu no Brasil, no início dos anos 1960 a democracia não era racional para a classe empresarial, e se tornou racional - mais capaz de atender à necessidade de bem-estar e segurança econômicos dessa classe - após o final dos anos 1970. Porém, como Alexander adota um método hipotético-dedutivo, da escolha racional, ele não tem uma resposta à questão que tão corretamente coloca. Alexander (2002:66-67) praticamente admite os limites de seu método quando se pergunta: em que condições os atores políticos poderão prever que as recompensas esperadas da democracia serão previsivelmente maiores do que as do autoritarismo? E ele responde: "colocar essa questão é o máximo a que os princípios da escolha racional podem nos levar". Vários fatores diminuem as recompensas esperadas pela direita de projetos autoritários, "mas eles só podem fazer isso numa base que os atores percebam como temporária, e podem assim induzir apoio temporário à democracia. Mas não podem influenciar as recompensas esperadas de um modo que os atores percebam como previsível e, portanto, não podem criar compromisso com a democracia ou com a consolidação democrática". Desse modo, ele reconhece não ter uma teoria geral da transição e da consolidação democráticas. Como partiu de hipóteses corretas e colocou uma excelente questão, se tivesse adotado uma abordagem histórica ele provavelmente teria sido mais conclusivo. Ele quase faz isso, ao salientar o papel dos fatores estruturais na transição e na consolidação democráticas, mas, no final, não consegue identificá-los. Afirma que "os conservadores europeus só consideraram mais atraente a previsibilidade da democracia quando acreditaram que havia ocorrido uma mudança em um fator 'estrutural'". Qual é esse fator estrutural? Ele ocorreu, segundo Alexander, "quando eles [os conservadores europeus] acreditaram que a esquerda havia se tornado previsivelmente moderada, não apenas taticamente moderada". Esse fato corresponde mais ou menos à segunda condição histórica para a consolidação democrática que apresentei neste trabalho: a perda, pelos ricos, do medo da expropriação. Ele não explica, porém, por que a classe capitalista foi capaz de modificar sua visão sobre o comportamento da esquerda ou dos trabalhadores, enquanto as classes dominantes precedentes não o foram. 


\section{AS EVIDÊNCIAS}

Dahl (1989) escreve sobre três períodos de crescimento da poliarquia: 1776-1930, 1950-1959 e os anos 1980. Huntington (1991), provavelmente inspirado nisso, identifica três ondas de democratização. Em cada onda, os países que tinham se tornado capitalistas e liberais fizeram sua transição para a democracia como previsto, enquanto os outros simplesmente os acompanharam como resultado de imitação, pressão dos pobres ou pressão de outros países. No final do século XX, além da maior parte dos países europeus e de língua inglesa, todos os países latino-americanos e um número cada vez maior de países nos outros continentes eram democráticos. A democracia tinha se disseminadoa forma de governo predominante. Nos países asiáticos, que vinham experimentando um extraordinário processo de crescimento econômico desde os anos 1950, as elites burocráticas e capitalistas resistem à democracia, mas, na última década, as transições democráticas tornaram-se uma realidade. $\mathrm{O}$ modelo apresentado neste trabalho pretende oferecer uma explicação geral da transição e da consolidação democráticas baseada no pressuposto de que a mesma teoria deve explicar ambos os fenômenos, mas está em terreno mais firme no segundo do que no primeiro. Historicamente, uma mudança completa da apropriação do excedente econômico pelo Estado para a apropriação pelo mercado é uma condição necessária e suficiente para a consolidação democrática, mas não para a transição democrática. Nenhum país experimentou a consolidação democrática antes de ter mudado a coordenação da economia, do Estado para o mercado, e de ter reduzido substancialmente os aspectos patrimoniais de seu Estado, mas o mesmo não pode ser dito em relação à democratização. Muitos países fazem suas transições para a democracia enquanto a captura do Estado pelos interesses privados permanece crucial para as elites; a democracia resultante é, porém, instável.

Quanto às transições democráticas, temos muitos casos de países que se tornaram democráticos antes que a revolução capitalista pudesse ser considerada completada; e também uma série de países que só fizeram sua transição tardiamente, muito depois de terem desenvolvido uma classe empreendedora e uma ampla classe média; ou que ainda são autoritários, como no caso de Cingapura. Com relação à consolidação democrática, no entanto, os casos excepcionais são poucos. Provavelmente o mais extraordinário caso de uma democracia consolidada estabelecida em um país em que as condições para isso não estavam 
claramente presentes seja a Índia. É provável que líderes esclarecidos como Gandhi e Nehru tenham desempenhado um papel importante, mas quando a transição ocorreu, já havia uma grande classe capitalista na Índia. Por outro lado, os trágicos fracassos da democracia depois da Primeira Guerra Mundial - particularmente na Alemanha - são uma exceção à nossa regra, mas devemos levar em conta que a transição para a democracia nesse país ocorreu logo após a guerra, em uma situação de profundo ressentimento com relação à derrota, às condições impostas pelos vencedores e à hiperinflação que se seguiu. Além desse caso, não vejo nenhuma exceção a essa generalização. Empiricamente não é fácil demonstrar sua validade, mas acredito que já existem evidências suficientes de que essa alegação é verdadeira. Os países de renda média que saíram do estatismo ou do comunismo, como a Polônia ou a Hungria, são exceções apenas aparentes ao meu argumento sobre a consolidação. $\mathrm{O}$ estatismo pretendia ser um meio para o socialismo, mas acabou sendo um caminho para a industrialização e o capitalismo. Quando houve a rápida transição do estatismo para o capitalismo, paradoxalmente a maior parte da revolução capitalista já havia acontecido sob o comunismo. Essas sociedades eram objeto de forte intervenção artificial ou planejada, mas seus níveis de renda, educação, tecnologia, além de vários aspectos de seu sistema de valores e de sua estrutura social, eram razoavelmente compatíveis com os requisitos da democracia consolidada.

A experiência histórica mostra que, depois que um país completa sua revolução capitalista, ele tenderá a se tornar democrático; posteriormente, quando se torna democrático, sua democracia será consolidada. Além da observação histórica geral, seria possível dispor de evidências mais fortes de que um país que tenha preenchido os requisitos históricos para a democracia, e se democratizado, não voltará a cair no autoritarismo? Este é um ensaio interpretativo, utilizando uma abordagem abrangente para identificar uma trajetória comum de longo prazo; ele não entra em mecanismos causais precisos e diferenças transnacionais sobre as maneiras pelas quais os países chegaram à democracia. Não realizei novas pesquisas sobre o tema. As evidências já disponíveis, porém, sustentam fortemente a hipótese apresentada aqui sobre a consolidação da democracia. Toda a literatura que associa democracia ao desenvolvimento econômico na verdade a apoia. Depois do clássico trabalho de Lipset, todas as pesquisas confirmaram esse achado básico. Quanto mais economicamente avançado for um Estado-nação, mais democrático ele será. 
Assim, a simples observação histórica confirma essa alegação, mas os estudos de Przeworski e seus colaboradores (2000) sobre desenvolvimento econômico e democracia oferecem uma comprovação definitiva. Em seu estudo sobre democracia no período 1950-1990, eles vão além de apenas mostrar a relação positiva entre ambos os fenômenos. Eles também demonstram que "quando estão estabelecidas, as democracias são muito mais passíveis de perdurar nos países mais altamente desenvolvidos". O achado central, porém, é mais específico: eles concluem que, nas democracias ricas (mais de seis mil dólares per capita ao ano) a probabilidade de que o regime volte a ser uma ditadura é praticamente zero. Os autores afirmam que seus achados não permitem estabelecer uma conexão causal. Mas acredito que a hipótese de que países não exportadores de petróleo, com renda per capita acima deseis mil dólares ao ano, completaram sua revolução capitalista é uma hipótese razoável ou conservadora. Se aceitarmos isso, segue-se que a conclusão do processo de modernização implica consolidação democrática. Como já admiti, há exceções a essa regra, mas são poucas. Przeworski e seus colaboradores não acharam nenhuma.

\section{CONCLUSÃO}

Resumindo, a transição democrática foi o resultado de quatro fatos históricos novos, todos relacionados à revolução capitalista, envolvendo a remoção dos dois vetos exercidos pelos ricos. Além disso, a hipótese desenvolvida aqui depende de duas condições: a falta de interesse dos trabalhadores em uma revolução socialista e a constância, a longo prazo, da taxa de lucro enquanto os salários e ordenados aumentam com a produtividade. Quando um país satisfaz todos esses requisitos e a transição ocorre, a democracia resultante será uma democracia consolidada. A mesma teoria que explica por que a democracia se tornou generalizada no século XX explica a consolidação mais especificamente, país por país.

O modelo de consolidação democrática apresentado aqui não estabelece uma conexão causal definitiva. Mas mostra que, em uma sociedade em que os lucros e os salários obtidos no mercado se tornam a forma predominante de apropriação do excedente - indicação central de que a revolução capitalista foi completada - as elites deixam de vetar a democracia. Posteriormente, à medida que os direitos de voto vão sendo estendidos para os pobres, as elites capitalistas percebem que essa mudança realmente não ameaça os direitos de propriedade e os contratos. 
Os trabalhadores, por sua vez, aumentam suas demandas de participação política, mas fazem isso de modo moderado. Por fim, as elites acabam percebendo, com base em suas próprias experiências e nas de outros países, que a democracia promove melhor seus interesses do que os regimes autoritários: é mais estável e prevê normas para que seus muitos membros repartam o poder e nele se alternem. As classes médias, que crescem de modo extraordinário, sentem a mesma coisa. Em outras palavras, depois que uma revolução industrial torna a apropriação do excedente econômico dependente não do controle do Estado, mas do mercado, os regimes autoritários deixam de ser atraentes para os capitalistas. Em um segundo momento, a classe profissional que recebe ordenados em lugar de salários cresce e divide o poder com os capitalistas. Ela também não tem razão para preferir o autoritarismo. Por fim, a democracia torna-se racional para todas as classes, a pesar da insatisfação que a partilha do poder sempre causa.

Qual é a relevância da teoria apresentada neste trabalho? Primeiro, permite compreender melhor o passado. Com ele, compreendemos por que a democracia se tornou a forma de governo preferida e generalizada somente no século XX. Segundo, por que a democracia se consolidou inicialmente nos países que primeiro sofreram revoluções capitalistas, isto é, Inglaterra e Estados Unidos. Terceiro, temos agora um critério para prever se um país que faz sua transição para a democracia acabará sendo uma democracia consolidada. Se emergir de modo endógeno, como um produto da revolução capitalista e da superação do medo da expropriação, ela será consolidada, mas se for o produto de pressões externas ou da tentativa das elites locais de imitar as instituições das sociedades mais avançadas, ela não o será. O México, por exemplo, levou muito tempo para tornar-se uma democracia, mas quando o fez já era uma democracia consolidada, enquanto a Venezuela e a Colômbia, que alcançaram antes a democracia, ainda não são democracias consolidadas. Quarto, ela nos leva a considerar um caso como o de Cingapura - um país rico, mas, apesar disso, ainda sob um regime autoritário - como a exceção, não a regra. Quinto, ela sugere que a pressão em favor da democracia sem que estejam presentes as condições para a democracia pode ter sentido para os países mais ricos, interessados em ter o estado de direito em suas relações econômicas com outros países, mas não será necessariamente a melhor opção para os países sob pressão. Pessoalmente, acredito que os países africanos pobres, por exemplo, deveriam ser democráticos para escapar da 
armadilha da pobreza, mas ninguém pode ter certeza sobre esse assunto.

(Recebido para publicação em novembro 2010)

(Aprovado para publicação em maio de 2011)

\section{NOTAS}

1. Sobre o "método histórico-dedutivo", ver Bresser-Pereira (2009); sobre "mecanismos sociais", ver Elster (1998) e a coleção editada por Hedström e Swedberg (1998).

2. Observe-se que eu uso as palavras "liberal" e "liberalismo" em seu sentido clássico, como a ideologia que, na esfera política, afirma o estado de direito e os direitos civis, e na esfera econômica, a coordenação da economia pelo mercado. Não uso essas palavras no sentido coloquial norte-americano de uma ideologia progressista que se inclina favoravelmente à intervenção do Estado para complementar a coordenação do mercado.

3. Podemos também ver uma tendência democrática em Thomas Paine e em Tocqueville.

4. Utilizei essa abordagem, originalmente, em 1978 para analisar e prever a transição brasileira para a democracia que ocorreria oito anos depois. Presumi que o Brasil já tivesse completado sua revolução capitalista. Mas, em razão da revolução cubana de 1959 e da radicalização política que se seguiu, a burguesia brasileira optou, em 1964, por um regime autoritário. Treze anos depois, no entanto, esse medo havia desaparecido, e a classe capitalista gradualmente se aliou às outras fontes de pressão democrática (Bresser-Pereira, 1978; 1984).

5. Observe-se, no entanto que, embora eu acredite que a distinção de Dahl entre democracia moderna e poliarquia seja útil em certas circunstâncias para distinguir uma forma ideal de governo da realidade, e também da democracia grega, neste trabalho utilizo "democracia moderna" ou simplesmente "democracia" e "poliarquia" como sinônimos.

6. De acordo com Montesquieu (1748:609) "où il y a du commerce, il y a des moeurs doux" ("onde há comércio, os costumes são suaves").

7. Nos Estados Unidos, o sufrágio universal masculino já existia desde a primeira parte do século XIX, provavelmente porque os norte-americanos foram os primeiros a se livrar do medo da expropriação.

8. O ensaio de Therborn sobre esse assunto (1977) ainda é a referência básica; o livro de Collier de 1999 sobre a classe trabalhadora e as elites na Europa Ocidental e na América do Sul oferece uma contribuição importante para o tema. Ver, também, Huber, Rueschmeyer e Stephens (1997), e Collier e Mahoney (1997). 


\section{Luiz Carlos Bresser-Pereira}

9. Pensou-se durante algum tempo que o socialismo seria essa alternativa, mas ele transformou-se em estatismo porque os burocratas, não os trabalhadores, substituíram os capitalistas, e o estatismo, depois de ter conseguido provocar um crescimento inicial, não foi capaz de coordenar sistemas econômicos mais complexos e torná-los competitivos.

10. Mainwaring (1992:327) observa que "a mais importante linha divisória nos trabalhos atuais sobre democracia está entre aqueles que a veem basicamente como resultado de condições econômicas, sociais ou culturais propícias, e aqueles que a veem basicamente como resultado de instituições políticas, processos e liderança". Como mostram esta crítica e todo o trabalho, eu me incluo na primeira tradição de pensamento, que também identifico como abordagem histórica.

\section{REFERÊNCIAS BIBLIOGRÁFICAS}

ACEMOGLU, Daron e ROBINSON, James A. (2006), Economic Origins of Dictatorship and Democracy. Cambridge, Cambridge University Press.

ALEXANDER, Gerard. (2002), The Sources of Democratic Consolidation. Ithaca, Cornell University Press.

BOBBIO, Norberto. (1991), Três Ensaios sobre Democracia. São Paulo, Cardim \& Alario Editora.

BOIX, Charles. (2003), Democracy and Redistribution. Cambridge, Cambridge University Press.

e STOKES, Susan C. (2003), “Endogenous Democratization”. World Politics, no 55, pp. 517-549.

BRESSER-PEREIRA, Luiz Carlos. (1978), O Colapso de uma Aliança de Classes. São Paulo, Editora Brasiliense.

(1984), "The Dialectic of Redemocratization and Abertura", in L. C. Bresser-Pereira, Development and Crisis in Brazil: 1930-1983. Boulder, CO, Westview Press, pp. 186-204.

(1986), Lucro, Acumulação e Crise. São Paulo, Editora Brasiliense.

(2004), "Growth and Distribution: A Revised Classical Model". Disponível em www.bresserpereira.org.br.

. (2009), "Os dois métodos e o núcleo duro da teoria econômica". Revista de Economia Política, vol. 29, № 2, PP. 163-190.

CAREY, John M. (1997), "Institutional Design and Party Systems", in L. Diamond et alii. (eds.), Consolidating the Third Wave Democracies. Baltimore, Johns Hopkins University Press, pp. 67-92. 
COLLIER, Ruth Berins. (1999), Paths toward democracy. Cambridge, Cambridge University Press.

e MAHONEY, James. (1997), “Adding Collective Actors to Collective Outcomes: Labor and Recent Democratization in South America and Southern Europe". Comparative Politics, vol. 2, no2, pp. 285-304.

CUTRIGHT, Philips. (1963), “National Political Development: Measurement and Analysis". American Sociological Review, no 28, abril, pp. 253-264.

DAHL, Robert. (1971), Polyarchy. New Haven, CT, Yale University Press. . (1989), Democracy and its Critics. New Haven, Yale University Press.

DAHRENDORF, Ralph. (2000), "Afterword to Disaffected Democracies", in S. J. Pharr e R. D. Putnam (eds.), Disaffected Democracies. What's Troubling the Trilateral Countries?. Princeton, Princeton University Press, pp. 311-314.

DIAMOND, Larry. (1997), "Introduction to Consolidating the Third Wave Democracies", in L. Diamond et alii (eds.), Consolidating the Third Wave Democracies. Baltimore, Johns Hopkins University Press, pp. xxiii-xlvii.

_et alii (eds.). (1997), Consolidating the Third Wave Democracies. Baltimore, Johns Hopkins University Press.

DUNN, John. (1979), Western Political Theory in Face of the Future. Cambridge, Cambridge University Press.

ELSTER, Jon. (1998), “A Plea for Mechanisms”, in P. Hedström e R. Swedberg (eds.), Social Mechanisms. Cambridge, Cambridge University Press, pp. 45-73.

FURTADO, Celso. (1976). Prefácio à Nova Economia Política. Rio de Janeiro, Paz e Terra.

GORVIN, Ian. (1989), Elections since 1945: A World-Wide Reference Compendium. London, Longman Group.

HABERMAS, Jürgen. ([1988] 1996), "Popular Sovereignty as Procedure". Appendix I of J. Habermas, Between Facts and Norms. Cambridge, MIT Press.

HANDELMAN, Howard e TESSLER, Mark (eds.). (2000), Democracy and its Limits. Notre Dame, University of Notre Dame Press.

HEDSTRÖM, P. e SWEDBERG, R. (eds.). (1998), Social Mechanisms. Cambridge, Cambridge University Press.

HIRSCHMAN, Albert O. (1977), The Passions and the Interests. Princeton, NJ, Princeton University Press.

HUBER, Evelyne; RUESCHEMEYER, Dietrich e STEPHENS, John D. (1997), "The Paradoxes of Contemporary Democracy: Formal, Participatory and Social Dimensions". Comparative Politics, vol. 2, no 2, pp. 323-342.

HUNTINGTON, Samuel P. (1991), The Third Wave. Norman, University of Oklahoma Press.

LANE, Erik-Jan; McKAY, David e NEWTON, Kenneth. (1997), Political Data HandbookOECD Countries. 2a ed. Oxford, Oxford University Press.

LINDBLOM, Charles. (1977). Politics and Markets. Nova York, Basic Books. 


\section{Luiz Carlos Bresser-Pereira}

LINZ, Juan J. (1990), "Transitions to Democracy". Washington Quarterly, no 13, pp. 143-164.

; STEPAN, Alfred. (1996), Problems of Democratic Transition and Consolidation. Baltimore, Johns Hopkins University Press.

LIPSET, Seymour M. (1959), “Some Social Requisites of Democracy: Economic Development and Political Legitimacy". American Political Science Review, no 53, pp. 69-105.

MACPHERSON, C. B. ([1966] 1972), The Real World of Democracy. New York, Oxford University Press.

MAINWARING, Scott. (1992), "Transitions to Democracy and Democratic Consolidation: Theoretical and Comparative Issues", in S. Mainwaring, G. O'Donnell e J. S. Valenzuela (eds.), Issues in Democratic Consolidation: The New South American Democracies in Comparative Perspective. Notre Dame, University of Notre Dame Press, pp. 294-341.

. (2000), "Democratic Survivability in Latin America", in H. Handelman e M. Tessler (eds.), Democracy and its Limits. Notre Dame, University of Notre Dame Press, pp. 11-68.

; O'DONNELL, Guillermo e VALENZUELA, J. S. (eds.). (1992), Issues in Democratic Consolidation. The New South American Democracies in Comparative Perspective. Notre Dame, University of Notre Dame Press.

MIDLARSKY, Manus I. (ed.). (1997), Inequality, Democracy, and Economic Development. Cambridge, Cambridge University Press.

MONTESQUIEU. (1748) [1995], L'Esprit des Lois. Paris, Editions Gallimard.

MOORE, Barrington, Jr. (1966), Social Origins of Dictatorship and Democracy - Lords and Peasants in the Making of the Modern World. Boston, Beacon Press.

MULLER, Edward N. (1997), "Economic Determinants of Democracy", in M. I. Midlarsky (ed.), Inequality, Democracy, and Economic Development. Cambridge, Cambridge University Press, pp. 133-155.

NOHLEN, Dieter (ed.). (1993), Encyclopedia Electoral Latinoamericana y del Caribe. San José da Costa Rica, Instituto Interamericano de Derechos Humanos.

O’DONNELL, Guillermo. (1991), "Delegative Democracy". Journal of Democracy, vol. 5, pp. 55-69.

(1997), "Illusions about Consolidation", in L. Diamond et alii (eds.), Consolidating the Third Wave Democracies: Themes and Perspectives. Baltimore, Johns Hopkins University Press, pp. 40-57.

. (2004), "Human Development, Human Rights, and Democracy", in G. O'Donnell, J. V. Culell e O. M. Iazzetta (eds.), The Quality of Democracy. Notre Dame, University of Notre Dame Press, pp. 9-92.

; CULLEL, Jorge Vargas e IAZZETTA, Osvaldo M. (eds.), (2004), The Quality of Democracy. Notre Dame, University of Notre Dame Press.

; SCHMITTER, Philippe e WHITEHEAD, Laurence (eds.). (1986), Transitions from Authoritarian Rule. Baltimore, John Hopkins University Press. 


\section{Transição, Consolidação Democrática e Revolução Capitalista}

PHARR, Susan J. e PUTNAM, Robert D. (eds.). (2000), Disaffected Democracies. What's Troubling the Trilateral Countries?. Princeton, Princeton University Press.

POCOCK, J. G. A. (1975), The Machiavellian Moment. Princeton, Princeton University Press.

PRZEWORSKI, Adam. (1985), Capitalism and Social Democracy. Cambridge, Cambridge University Press.

et alii. (2000), Democracy and Development: Political Institutions and Well-Being in the World, 1950-1990. Cambridge, Cambridge University Press.

PUTNAM, Robert D.; PHARR, Susan J. e DALTON, Russel J. (2000), “What's Troubling the Trilateral Democracies?", in S. J. Pharr e R. D. Putnam (eds.), Disaffected Democracies: What's Troubling the Trilateral Countries?. Princeton, Princeton University Press, pp. 3-30.

RUESCHEMEYER, Dietrich; STEPHENS, Evelyne Huber e STEPHENS, John D. (1992), Capitalist Development \& Democracy. Chicago, Chicago University Press.

RUSTOW, Dankwart A. (1970), “Transitions to Democracy: Toward a Dynamic Model”. Comparative Politics, vol. 2, no 2, pp. 337-363.

SANTOS, Wanderley Guilherme dos. (1998), “Poliarquia em 3D”. DADOS, vol. 41, no 2, pp. 207-282.

SCHMITTER, Philippe. (1997). "Civil Society East and West", in L. Diamond et alii (eds.), Consolidating the Third Wave Democracies: Themes and Perspectives. Baltimore, Johns Hopkins University Press, pp. 239-262.

SIMON, Herbert A. (1957), Models of Man. New York, Wiley.

THERBORN, Goran. (1977), "The Rule of Capital and the Rise of Democracy". New Left Review, no 103, pp. 3-41.

VALENZUELA, J. S. (1992), “Democratic Consolidation in Post-transitional Settings: Notion, Process, and Facilitating Conditions", in S. Mainwaring, G. O'Donnell e J. S. Valenzuela (eds.), Issues in Democratic Consolidation: The New South American Democracies in Comparative Perspective. Notre Dame, University of Notre Dame, pp. 57-104.

WEFFORT, Francisco. (1984), Por que Democracia?. São Paulo, Editora Brasiliense. 


\section{ABSTRACT \\ Democratic Transition, Consolidation and Capitalist Revolution}

Democracy only became the preferred form of government in the $20^{\text {th }}$ century. The new historical fact that led to the change in preference was the capitalist revolution, which changed the mode of appropriation of the surplus, from violence to the market. Disappearance of fear of expropriation, the emergence of the middle classes, and pressure from the poor were the second, third, and fourth new historical facts that opened the way for the democratic transition. After these four conditions had been met, universal suffrage was guaranteed. The theory presented here does not predict transitions, since countries rarely become democratic without completely meeting historical conditions, but it does predict democratic consolidation, since no country that has completed its democratic revolution slips back into authoritarianism.

Key words: democracy; economic development; capitalist revolution

\section{RÉSUMÉ}

\section{Transition, Consolidation Démocratique et Révolution Capitaliste}

Ce n'est qu'au XXème siècle que la démocratie est devenue le type de gouvernement préféré. Le fait historique nouveau menant à ce changement a été la révolution capitaliste qui a transformé le mode d'appropriation des excédents par la violence déplacée au marché. La disparition de la peur de $l^{\prime}$ expropriation, $l^{\prime}$ avènement des classes moyennes et la pression des pauvres sont les deuxième, troisième et quatrième faits historiques nouveaux ouvrant le chemin à la transition vers la démocratie. Après que ces quatre conditions ont été remplies, le suffrage universel a été assuré. La théorie proposée ici ne prévoit pas de transitions, puisque les pays deviennent rarement démocratiques sans un aboutissement des conditions historiques, mais elle prévoit la consolidation démocratique, car nul pays ayant achevé sa révolution démocratique ne revient à l'autoritarisme.

Mots-clés: démocratie; développement économique; révolution capitaliste 